\title{
ORIENTATION OF SASI CULTURAL VALUES IN MALUKU
}

\author{
Jenny Koce Matitaputty ${ }^{1}$ \\ ${ }^{1}$ Faculty of Teacher Training and Education, Pattimura University
}

\begin{abstract}
More than the cultural values contained in the management of natural resources in Maluku will always include the principles and traditions of sasi and adat because they are an intrinsic part of a culture which for centuries has proven to be adaptive and resistant to external disturbances. The purpose of this study was to determine the orientation of the cultural value of sasi in Maluku. The method used is qualitative research, where observation, interviews and documentation are used to collect data from informants. The results showed that talking about cultural values in sasi would be related to the concept of the nature of human life, the work of human life, human position and space and time, the nature of man and nature as well as the relationship between humans and humans and other people. Where the culture of sasi illustrates what humans must do, It is hoped that sasi culture will remain a part of the Saparua indigenous people so that people will continue to choose the values of sasi cultural orientation so that social life and ecological life will continue to be sustainable from the control of sasi cultural values.
\end{abstract}

\section{Introduction}

Indonesia has a very large wealth of natural resources but for many years has suffered from the Dutch syndrome disease, namely exploiting natural resources excessively to generate their profits without regard to natural resources [1].

From the data obtained in the research conducted [2], it was found that (1) In Java and Kalimantan, with deforestation rates reaching 1.8 hectares/year, 21\% of Indonesia's 133 million hectares of forest are lost. The loss of forests causes environmental damage, increases natural disasters, and threatens extinction to preserve flora and fauna. (2) $30 \%$ of Indonesia's 2.5 million hectares of coral reefs were damaged. Damage to coral reefs results in disaster risk in coastal areas, threatens marine biodiversity and reduces marine fishery production

Increasing environmental degradation in much of the developing world is often linked with rapid economic development and the loss of indigenous knowledge systems and traditional resource management institutions [3]. Hence local, customary or situational knowledge has a voice in development and conservation discourse [4]. This states that the recent ecological crisis has created a new awareness that the ecological crisis can be saved by returning to the ethics of indigenous peoples, namely their local wisdom [5].

Local wisdom is basic knowledge gained from living in balance with nature. It is related to culture in the community, which is accumulated and passed on [6]. The same 
thing is stated by Dahliani et al. [7]. Local wisdom means the harmonious relationship between man, nature and the built environment in an area also influenced by its culture.

One form of local community wisdom that regulates the utilization and management of natural resources is found in Maluku, known as sasi [8]. In Maluku Province, Indonesia, natural resources are managed under a locally defined set of rules and regulations known as sasi [9] Tradition of Maluku in Lease of Middle Maluku Regency well know called "Sasi" [10]

Sasi has the principle of sustainability and balance of human and natural relationships and a man with the creator. Sasi is in line with sustainability is the dream of living well; sustainability is a dynamic balance with others and the environment; it is the harmony [11]

Sasi was, therefore, renewed as community-based management, as 'environmental wisdom' applied to sustainability problems [12]. The role of local resource management institutions is described generically in the Moluccan islands as sasi, and how these have been adapted to modern purposes [13].

Based on its practical implementation, Sasi can be defined as a system of cultural values concerning the management of natural resources (forests and sea) at certain time intervals, which are adjusted to the types of natural resources that are confined both in the sea and forest. Protecting the ecosystem for sustainable living, both for humans (a guaranteed supply of foodstuffs), plants, animals, and oceans, are based on the notion of a sustainable process of living things [14]. But in reality, overexploitation without careful planning leads to disaster. As a result, natural resource management does not pay attention to environmental balance and preservation. Therefore sasi acts as a cultural value that must be inherited to support natural resources to continue to grow and develop for the next generation

\section{Literature Review}

\subsection{Sasi Culture In Maluku}

Sasi is a conventional resource management system in the eastern part of Indonesia, encompassing spatial and temporal prohibitions on harvesting crops, cutting wood, and gathering other products from the forest, tidal zone, or marine territory [15]. According to the customary community, Sasi is a complete prohibition to protect something or specific results within a certain time limit. It is enforced with specific marks and has characteristics or legal provisions that generally apply [16].

To maintain a balance between humans and life, which contains prohibitions and management of natural resources for a certain period, it is called Sasi [17]. Thus sasi can answer the goal of the modern world to live in harmony with nature as proposed by Ellen role of local institutions of resource management described generically in the Moluccan islands as sasi, and how these have been adapted to modern purposes.

In general, the Sasi throughout the Maluku Islands has a similar mechanism, namely "buka sasi" (literally means the opening of the sasi period) and "tutup sasi' (literally means the closing of the sasi period). During the Buka Sasi period, community members are allowed to use natural resources according to their needs. The length of time to open and close the sasi depends on the condition of natural resources and the rules of the kewang [18].

In order sasi regulations can be enforced, the traditional institutions that have authority in the management of natural resources and environmental conservation are still there and still perform their function is is "Kewang Organization" (stewards of the environment) [19]. 
Kewang, an adat enforcement organization, plays a central role in village resource management in the more traditional villages with an active sasi institution. sasi is a system under which particular areas, crops or resources on land or in the sea may be put under harvest prohibition for limited periods. Kewang members, selected under rules that vary from place to place, act as unoffical police, guarding those crops and marine resources under sasi [20].

Kewang can also be interpreted in the system of formal government as Port Administrator, Department of Fisheries and Marine Affairs, the Department of Transportation, Water Police and Maritime Security Coordinating Board, but against governmental bodies are in terms Kewang is an institution that is integrated into a unity of command and unity institutional Internalization of institutional arrangements Kewang in the national legal system for setting marine in Maluku [21].

\subsection{Varian in value orientation}

To see how the Sasi culture can continue to live in a cultured society, argues that four cultural forms are symbolically depicted as four concentric circles with cultural values related to the relationship between humans and nature. Its surroundings are illustrated as follows. The four concentric circles represent the outside in, Namely, first, the outermost circle, the set of elements of physical culture; second, the circle within it, the social system; third, the circle within it, the ideal system of culture; and fourth, the deepest circle, cultural values [22]

The main study in this research is the cultural value system, which is the highest and most abstract level of culture. This is because cultural values are concepts about what lives in most people's minds about what they consider valuable, valuable and important in life so that they can function as a guide that gives direction and orientation to life. Culture refers to the system of values, beliefs, and ideas that social groups use in experiencing the world in mutually meaningful ways. Management of environment for sustainability is the concept from indigenous people customary [23].

The five common human problems, posed as questions, that provided the most useful "value orientations" in creating a cultural typology were: [24]

1) What is the temporal focus of life? (Time orientation)

2) What is the modality of human activity? (Activity orientation)

3) What is the modality of a person's relationship to others in the group? (Relations orientation)

4) What is the relationship of people to nature? (Person-nature orientation)

5) What is the character of innate human nature? (Human nature orientation)

Technically, the five principles above are called cultural value orientation. Mention concepts that affect the five issues of value in life (the five cultural orientations) which are the contents of the cultural value system in cultural unity. The concepts in the following table:

Table 1. Varian in value orientation

\begin{tabular}{|c|c|c|c|c|}
\hline No & Orientasi & \multicolumn{3}{|c|}{ Variasi konseps orientasi nilai budaya } \\
& & Good & Mixture of food and evil & Evil \\
\hline 1 & Human relations & Harmony with nature & Mastery over nature \\
\hline 2 & Man nature & Subjections nature & Present & Future \\
\hline 3 & Time & Past & Being in becoming & Doing \\
\hline 4 & Activity & Being & Collaterality & individuallity \\
\hline 5 & Relational & Lineallity & & \\
\hline
\end{tabular}


Sumber: Modification [24] and [25]

The conception of the contents of the cultural value system, which is universally present in every culture in the world was developed by is variation in values orientation [26].

\section{Methodology}

This Studi uses an ethnographic research method to describe, analyse and interpret the cultural community. Ethnographic research is a qualitative design for describing, analysing and interpreting the patterns of a culture sharing group. Cultures are a broad term used to encompass all human behaviour and beliefs [27]. Therefore, research is the key instrument. The most important informant was Rajaor, the village leader and kewang. Because it is difficult to find the culture of sasi on Ambon Island, which is carried out by kewang, this research was conducted on the island of Saparua.

The data collection technique in this research is observation and interviews. The observations are selected so that the researcher can see things that were not discussed in the interview. Researchers give the freedom of informants in answering questions to strengthen data obtained from observation. After that, Triangulation is done to validate one data source with other data sources [28].

\section{Result and Discussion}

The centre of this research is related to sustainable living in the use of natural resources through the cultural values of Sasi about Man Nature.

Many cultures conceptualize nature as something strong and perfect so that humans must submit to it (subjection to nature).

This shows the past; everything was done for survival with the interaction between nature and humans. Humans in the olden days used nature's language to form a built environment, namely the interaction between nature-human-built environment, in contrast to today, which prefers the technology [29].

Humans in the past used natural language to shape the built environment in their interactions; in contrast, today, humans prefer technology. In the past, humans implemented the language of nature, which was then used to manage nature. In this case, determinism views humans as passive figures so that their lives are only controlled by their natural surroundings. In other words, man cannot determine his own life. At this stage, the culture of the community for processing the environment is still shallow. In addition, humans tend to be passive in facing natural challenges. Action towards nature is simply a reaction to accepting things as they are. It can be concluded that at this stage, human activities are influenced by environmental conditions. Dependence on the environment can be seen from the livelihoods, behaviour, habits, and human culture in a particular environment.

In the transitional period, the current orientation of humans about nature must be in harmony and relations with others more horizontally (collectively) or cooperation with others. A culture like this does not teach its community to submit to nature and try to dominate it but live in harmony (Harmony with nature). This concept is offered that the universe should not be viewed as a machine composed of a set of separate objects but as a harmonious whole that cannot be separated; A dynamic network that includes humans who have not an only ratio, but also essential intuition [30].

The development of technology that is not environmentally friendly and industrialized that exploits natural data sources should be able to be changed by adopting a paradigm in ways of thinking, empathizing, acting systemically, holistically and ecologically in line with the concept of sustainability [31]. The harmonious relationship with nature can be seen 
in the classical Chinese tradition in the Yin and Yang culture that influences each other in harmony. The same thing is found in the Sasi culture in Maluku to live in harmony with nature, in maintaining the sustainability of the ecosystem of living things. This is not just a hope for the future but must be started from today so that sustainable life will truly become a reality, especially if we look at the condition of the earth, which is increasingly damaged by the threat of Global Warming. The earth-saving campaign should not be just lip service, but hopefully, everyone can implement it for the next generation.

In line with Possibilism is a theory that reveals that humans determine their lives. Vidal de la Blache put forward this theory. Posibilism views humans as active creatures capable of cultivating nature to support their lives. This understanding says that humans are intelligent creatures. With the ability of his intellect, humans can respond to what nature provides. Possibilism also explains that nature can not always affect human life and activity, but that nature provides various choices and human responses to every preference given by nature. So it can be concluded that natural conditions are not a determining factor but a controlling factor. According to this understanding, nature does not act as a determinant but only provides opportunities. Humans play a role in determining the choices from the opportunities provided by nature.

Conversely, in a progressive period (Future), with future orientation to enhance prestige, relationships with others are more individual. There is a culture that teaches its people that even though nature is ferocious, reason must be able to unearth secrets and ultimately conquer and use them for its life purpose (mastery of harmony). With various efforts, humans try to conquer nature for its survival. The major forces that influence the relationship between humans and the environment are population growth, economic growth, technology and human attitudes [32]. A cultural value that has this orientation has motivated the development of science and technology.

In the development of modern history, the anthropocentric paradigm places humans at the centre and determinants of the historical process. Nature is considered an object that must be controlled and a mechanical system that can be engineered for the benefit of humans. The concepts of progress, productivity and growth are modern historical concepts characterized by exploitation. This is also explained later after utilizing nature, and a higher level is the use of the surrounding nature. Of course, this will cause a dysfunction in the balance of nature and discredit the role of nature as an element of life that has the right to protect [33].

Social inequality will arise as a result of excessive exploitation of nature / the environment when natural resources (SDA), which are God's gifts that we should be grateful for by making the best use of and preserving their sustainability, are overexploited without paying attention to aspects of the role and function of this nature in the environment. can bring various kinds of natural disasters that are very detrimental.

This point of view is unfair because it ignores natural rights, which also have their regulatory mechanisms. In an anthropocentric view, nature is seen as an object, tool or instrument and means to fulfil human needs. Nature is considered to have no value in itself. Therefore, the anthropocentric view needs to be abandoned because it threatens the sustainability of the planet earth and is changed to an ecocentric paradigm. Thus the culture of sasi has a good value for the people of Maluku, especially in the world of education seeing. It is hoped that the community will be able to maintain the natural ecosystem properly so that they will avoid illegal logging, harvesting raw fruit for market, taking fish from the sea with bombs, poison, and printer ink. by avoiding this, we have maintained the life chain in the natural ecosystem, even in meeting the needs of human life in the future.

In the end, the eco-centrism paradigm places humans, other creatures and the environment and the physical characteristics of nature as having an equal position. Humans are only part of the natural system and therefore bound by ethics and the obligation to 
maintain and preserve it for human life itself in the future. Defines that humans take a proactive position in the triangle between humans, nature and culture, which is not just cultured to respond to nature. Culture is simultaneously a symbol of human efforts to escape determinism.

Thus the Sasi culture must be preserved for the survival of both natural and human life in Maluku. The concept of local wisdom becomes a breakthrough for the community in maintaining the sustainability of the natural and cultural environment. This shows that the human position is very important and strategic. Because humans are the key to environmental change because humans and their behaviour can affect the survival of all existing creatures. Human behaviour towards nature shows a reciprocal relationship between humans and their environment. His relationship must run in harmony and become a commitment that demands that everything in the environment does not damage each other.

Talking about the sustainability of culture in sasi, it will be related to the orientation of cultural values in which it is related to the concept of the nature of human life, the work of human life, the position of man and time and space, the nature of man and nature and human relations with others. The culture of sasi describes what humans must do if in the past humans were only subject to nature, now along with the development of science and technology, humans begin to live in groups and then try to control nature but still live in harmony with nature and the future when they live individually the main thing is whether humans can still live in harmony with nature and other humans.

Thus, it is hoped that the sasi culture will remain a part of the Saparua indigenous people so that people will continue to choose the values of the sasi cultural orientation so that they can live sustainably, not control of nature, as stated by Kluckhon. and Stodbeck that the cultural values of sasi can be explained. In table 2:

Thus sasi is culturally oriented because humans must understand the nature of their life, how to live in harmony with nature so that it benefits their generation as was done by their ancestors, and how humans live with each other as social beings and how they are accountable to God the creator.

Table 2. The Orientation of Sasi Cultural Values

\begin{tabular}{|c|c|c|c|c|}
\hline \multicolumn{5}{|c|}{ The Orientation of Sasi Cultural Value } \\
\hline $\begin{array}{c}\text { Human } \\
\text { Orientation }\end{array}$ & $\begin{array}{l}\text { Man Nature } \\
\text { Orientation }\end{array}$ & Time Orientation & $\begin{array}{c}\text { Activity } \\
\text { Orientation }\end{array}$ & Relation \\
\hline $\begin{array}{l}\text { Life is something } \\
\text { that must be } \\
\text { fought for, life is } \\
\text { a choice for the } \\
\text { better or for the } \\
\text { worse. The } \\
\text { meaning of the } \\
\text { essence of life } \\
\text { makes humans } \\
\text { have to fight for } \\
\text { the survival of a } \\
\text { better life. } \\
\text { Sasi is in line } \\
\text { with } \\
\text { sustainability is } \\
\text { the dream of } \\
\text { living well; } \\
\text { sustainability is a } \\
\text { dynamic balance }\end{array}$ & $\begin{array}{l}\text { The orientation of } \\
\text { cultural values is } \\
\text { based on the view } \\
\text { that humans only } \\
\text { submit to nature, } \\
\text { live in harmony } \\
\text { with nature, or } \\
\text { control (destroy) } \\
\text { the nature given } \\
\text { by God. [35] } \\
\text { Sasi is not simply } \\
\text { an institution } \\
\text { designed to } \\
\text { regulate resource } \\
\text { use; sasi also has } \\
\text { a significant } \\
\text { cultural role. "It is } \\
\text { an encompassing } \\
\text { body of }\end{array}$ & $\begin{array}{l}\text { Sasi gives a very } \\
\text { important meaning } \\
\text { to the Saparua } \\
\text { indigenous people, } \\
\text { because sasi is not } \\
\text { only related to past } \\
\text { or present } \\
\text { orientation but also } \\
\text { to the future. } \\
\text { Without human } \\
\text { beings who are wise } \\
\text { and prudent in } \\
\text { managing the } \\
\text { wealth of natural } \\
\text { resources that exist, } \\
\text { over time along } \\
\text { with an } \\
\text { development of } \\
\text { science and and }\end{array}$ & $\begin{array}{l}\text { Humans will } \\
\text { always work for } \\
\text { their survival only } \\
\text { to get a position / } \\
\text { position or honor } \\
\text { or for prestige. In } \\
\text { this case, when } \\
\text { talking about sasi, } \\
\text { the role of } \\
\text { kewang with high } \\
\text { dedication is } \\
\text { difficult to find in } \\
\text { an individual } \\
\text { world. However, } \\
\text { community life is } \\
\text { still kinship to the } \\
\text { Saparua } \\
\text { indigenous } \\
\text { people. }\end{array}$ & $\begin{array}{l}\text { This social } \\
\text { sustainability can } \\
\text { be found through } \\
\text { the Ma'ano } \\
\text { culture, i.e. } \\
\text { helping each other } \\
\text { or helping to } \\
\text { harvest the results } \\
\text { of natural } \\
\text { resources. } \\
\text { Communal } \\
\text { ownership is } \\
\text { defined as a } \\
\text { shared ownership, } \\
\text { causing the right } \\
\text { and duty to } \\
\text { manage, maintain } \\
\text { and preserve it } \\
\text { together as a form }\end{array}$ \\
\hline
\end{tabular}




\begin{tabular}{|c|c|c|c|c|}
\hline $\begin{array}{l}\text { with others and } \\
\text { the } \\
\text { environment, it is } \\
\text { the harmony. } \\
\text { The economic } \\
\text { value of sasi } \\
\text { makes the } \\
\text { indigenous } \\
\text { Saparua people } \\
\text { protect their } \\
\text { natural resources } \\
\text { for a better life. } \\
\text { Sasi is very } \\
\text { beneficial for the } \\
\text { income of the } \\
\text { Saparua } \\
\text { indigenous } \\
\text { people because } \\
\text { the natural } \\
\text { resource yield of } \\
\text { sasi has a very } \\
\text { high economic } \\
\text { value, due to the } \\
\text { quality and } \\
\text { quantity of the } \\
\text { sasi harvest. } \\
\text { implementation } \\
\text { of the Sasi that is } \\
\text { not taken up by } \\
\text { the time the } \\
\text { results can be } \\
\text { harvested up to } \\
\text { the quality of the } \\
\text { results of the } \\
\text { earth and the sea, } \\
\text { so that it can } \\
\text { economically } \\
\text { productive [ } 34 \text { ] }\end{array}$ & 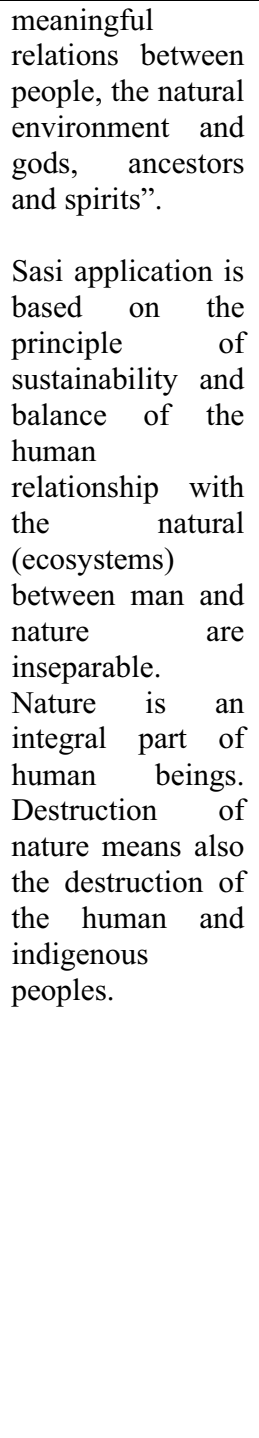 & $\begin{array}{l}\text { technology, if this is } \\
\text { not accompanied by } \\
\text { human intelligence, } \\
\text { the wealth of natural } \\
\text { resources will } \\
\text { become extinct and } \\
\text { human survival will } \\
\text { also become } \\
\text { irregular or } \\
\text { insecure. (because } \\
\text { nature has been } \\
\text { exploited and } \\
\text { damaged) } \\
\text { Sasi is a local } \\
\text { knowledge of } \\
\text { Saparua indigenous } \\
\text { community } \\
\text { that must be } \\
\text { maintained for the } \\
\text { sake of our } \\
\text { generation. }\end{array}$ & $\begin{array}{l}\text { Kewang operates } \\
\text { without } \\
\text { demanding } \\
\text { respect or making } \\
\text { a name for itself. } \\
\text { Kewang works } \\
\text { selflessly to } \\
\text { protect the } \\
\text { customary and } \\
\text { heritage } \\
\text { natural resources } \\
\text { for the life of the } \\
\text { Saparua } \\
\text { indigenous } \\
\text { people. } \\
\text { The clove that is } \\
\text { cultivated using } \\
\text { Sasi usually } \\
\text { produces more } \\
\text { fruits because it } \\
\text { has been prepared } \\
\text { before the trees } \\
\text { produce the fruit } \\
\text { by clearing the } \\
\text { area around the } \\
\text { forest so that the } \\
\text { sunlight will } \\
\text { provide maximum } \\
\text { yield production. } \\
\text { Supervision on } \\
\text { the natural } \\
\text { resource } \\
\text { management by } \\
\text { kewang affects } \\
\text { the abundant } \\
\text { clove products }\end{array}$ & $\begin{array}{l}\text { of existence of } \\
\text { indigenous } \\
\text { fellowship } \\
\text {. he Sasi affects } \\
\text { the } \\
\text { relationship } \\
\text { between } \\
\text { individuals and } \\
\text { clans as it } \\
\text { strengthens [36] }\end{array}$ \\
\hline
\end{tabular}

Sumber : Modification The orientation of sasi cultural values

Generally, the main motivation behind Sasi is the availability of life insurance; with this guarantee, human beings must take responsibility for maintaining the nature of creating a better quality of life by improving the quality of natural resources. Sasi can support the sustainable living of Saparua community economy. Example for marine products. For sea cucumbers, the bigger the size, the bigger the capacity, approximately 6-10 sea cucumbers for Rp 600,000; whereas without Sasi, they will only be consumed by the community. If they are sold before reaching the exact size, there will only be $10-15$ sea cucumbers $/ \mathrm{kg}$ with the low selling price. Meanwhile, lola slugs will grow to $1 \mathrm{~kg}$ using Sasi, with Rp 12,000 selling price. If Sasi is not used in the breeding process, lola slugs will only cost Rp 10,000 for $20 \mathrm{slugs} / \mathrm{kg}$, and the shells cannot be utilized [37].

Sasi is a communal practice that requires all members of the society to be responsible for maintaining natural resources. This sense of togetherness certainly creates harmony in the society so that villages that implement Sasi will look well-ordered, well organized, and 
clean. Signs of sasi also mean harmony in neighbouring villages to respect the village implementing sasi. Social sustainability arises when people believe that as human beings, they always live in need of one another, creating a variety of values of mutual respect, help, and high kinship to create a society that lives orderly and peacefully. In the context of ownership, resource and marine areas are owned collectively, not individually.

The role of sasi is illustrated by the three pillars of sustainability proposed [38] and the development continuity cycle, which adds the political and cultural elements by United Nations, making a strong sasi in the five pillars of sustainability for the survival of indigenous people of Maluku of sustainability economic-sosialenvironmet-culture and politic. [39] Complementing the basics of sustainability pillars in the triple bottom line and sustainability of UNESCO culture and sustainability, eggs sustainability models also illustrate patterns of relationships between humans and ecosystems as circles within other circles.

\section{Conclusion}

The Saparua indigenous people must preserve sasi as one of the local heritage rich in cultural values because it is precious for the people of Maluku, especially Saparua, in managing the use of natural resources that are not only environmentally friendly as recently discussed and announced since the beginning. 20-21 centuries. Long before modern society realized the importance of natural resource management for the sustainability of traditional knowledge, sasi local wisdom had been established in Maluku. To this day, Sasi has proven to be very important because it can support the sustainable living of the Saparua people.

\section{References}

1. Satria, A (2007) Penguatan Kapasitas Masyarakat Desa Dalam Akses dan Kontrol Terhadap Sumber Daya Alm. Makalah disampaikan dalam seminar dan Lokakarya menuju Desa 2030. Di Kampus Magister Manajmen dan Bisnis. IPB.Bogor.

2. Lisdiyono, E (2015) The Economic Value Of Nature and the principle of local wisdom as environmental protection effort in Indonesia. Ha125-32, Proceeding Kuala Lumpur International Business, Economics and Law Conference 7, Vol: 4. ISBN 978-967-11350-6-8

3. Novazek, I, Herkes, I.H.T., Sopacua J., Tutuhey,M (2001) An Institutional Analyzis Of Sasi Laut In Maluku, Indonesia. Canada, Ottawa, Malaysia. Danida, IDRC Canada, ICLARM the World Fish center.

4. Peet, M. and M.J. Watts, eds. (1996) Liberation Ecologies:Envirionment, Development, Social Movements. New York: Routledge

5. Keraf, A. S (2002) Etika Lingkungan. Jakarta: Kompas

6. Mungmachon (2012) Knowledge and Local Wisdom: Community Treasure : International Journal of Humanities and Social Science. Vol. 2 No. 13. PP. 174-181

7. Dahliani, Soemarno, I., Setijanti,P (2015) Local Wisdom in built environment in globalization era. International Journal of Education and Research. Vol. 3 No. 6, PP. 157-166

8. Matitaputty, J.K; Ali, M, Sjamsuddin, H, Maryani, E (2018) Model of Sustainable Development of Sasi from Maluku, Indonesia. Jour of Adv Research in Dynamical \& Control Systems, Vol. 10, 04-Special Issue hal. 981-984.

9. Harkes I (2001) An Institusional analysus of sasi laut, a fisheries management system in 
Indonesia. Proceedings of the International Workshop on Fisheries Comanagement.PP-1-9

10. Supusepa, R, Akub, S. Sofyan, A dan Karim, H,M.S (2014) Penal Mediation Role in Solving the criminal case. International journal of Advances Research, Vo.2 Issue.2 PP: $222-225$

11. Nirahua, S dan Kuahaty (2016) Authority of the Village in Maluku as Indigenous People in the Management of Natural Resources in the Sea Customary Rights. International Journal of Scientific and Research Publications, Volume 6, Issue 3, ISSN 2250-3153, PP 248-255

12. Ellen, R (2016) Nuaulu ritual regulation of resources, Sasi and forest conservation in eastern Indonesia. Journal South East Asia Research, 24, 1, pp 5-22doi: $10.5367 /$ sear.2016.0290

13. Ellen R (2013) Nuaulu protection of forest, forms of ritual regulation, and the recent history of forestry practices in eastern Indonesia. IUAES Manchester. Panel Title: Social Anthropology and Natural Resources

14. Matitaputty, J.K (2018) Budaya Sasi untuk menunjang sustainable living pada masyarakat adat Saparua dan Preservasinya melalui Pembelajaran Ilmu Pengetahuan Sosial di Universitas Pattimura. Disertasi

15. Harkes, I., \& Novaczek ( 2002) Presence, performance, and institutional resilience of Sasi, a traditional management institution in Central Maluku, Indonesia. Jurnal Ocean \& Coastal Management 45(4-5):237-260. http://dx.doi.org/10.1016/ S09645691(02)00057-1.

16. Renjaan, Justine, Purnaweni, Hartuti, \& Anggoro, Didi Dwi. (2013). "Studi kearifan lokal Sasi kelapa pada masyarakat adat di desa Ngilngof kabupaten Maluku Tenggara". Jurnal Ilmu lingkungan. Volume 11 Issue 1: 23-29 (2013). Semarang: Undip

17. Supusepa, R, Akub, S. Sofyan, A dan Karim, H,M.S (2014) Penal Mediation Role in Solving the criminal case. International journal of Advances Research, Vo. 2 Issue. 2 PP: $222-225$

18. Tjiptabudi, Y (2011) Asas Keseimbangan Dalam Pengelolaan Sumberdaya Alam Wilayah Laut dan Pesisir. Dissertation, Makassar, Universitas Hasanudin.

19. Nirahua, S dan Kuahaty (2016) Authority of the Village in Maluku as Indigenous People in the Management of Natural Resources in the Sea Customary Rights. International Journal of Scientific and Research Publications, Volume 6, Issue 3, ISSN 2250-3153, PP 248-255

20. Novaczek, I dan Herkes I (1999) Marine Resources Management in Central, Maluku Indonesia. Journal CAKALELE, VOL. 10 PP: 49-61

21. Lonthoir A, Asba, A.R., Tang,H.M., Hamdat,S (2016) Concept "Larvul Ngabal" Settings in Marine Resource Management in Southeast Maluku Kei Islands. International Journal of Scientific and Research Publications, Volume 6, Issue 1,PP: 524-530

22. Koentjaraningrat (2005) Pengantar Antropologi II ; Pokok-pokok Etnografi. Jakarta: Rineka Cipta

23. Rugrebert,V. R (2015) The environmental management philosophy of indegnous peoples in coastal marine in Maluku. International Journal of Advanced Research (2015), Volume 3, Issue 7, ISSN 2320-5407 . 1322-1329

24. Gallagher (2001) Understanding Other Cultures: The Value Orientations Method. Presented at the Association of Leadership Educators Conference, Minneapolis, MN 
25. Tutik, Titik, T., \& Trianto (2008) Dimensi Transendental dan Transformasi Sosial Budaya. Jakarta : Lintas Pustaka Publisher.

26. Kluckhon dan Strodtbeck (1961) Variations in value Orientation. Evanston, IL

27. Creswell, J.W (1997) Qualitative inquiri and research design; chosin among five tradisions : London; united kingdom ; sage publucation

28. Ali, M (2014) Memahami Riset Perilaku dan Sosial; Jakarta : Penerbit Bumi Aksara

29. Dahliani, Soemarno, I., Setijanti,P (2015) Local Wisdom in built environment in globalization era. International Journal of Education and Research. Vol. 3 No. 6, PP. 157-166

30. Capra, F (1982) The Turning Point (Titik Balik Peradaban, terj). Yogjakarta: Pustaka Promethea

31. Supriatna, N (2016) membangun Kesinambungan Diversity Hayati Indonesia Melalui Pembelajaran Sejarah Berbasisi Ekopedagogi. Pidato Pengukuhan Guru Besar.

Bandung : Universitas Pendidikan Indonesia.

32. Khan, R (2010) Critical peagogy, ecoliteracy \& planetary Crisis, The ecopedagogy, moement. New York: Peer Lang.

33. Kusumohamidjojo, Budiono (2009) Filsafat Kebudayaan; Proses Realisasi Manusia. Jogjakarta: Jalasutra

34. Nendissa, R. H (2010) Eksistensi Lembaga Adat Dalam Pelaksanaan Hukum Sasi di Maluku. Jurnal Sasi Vol. 16 No.4 PP: 1-6

35. Von Benda-Beckmann, F., K. Benda-Beckmann, and A. Brouwer. (1995) Changing Indigenous environmental law in the central Moluccas: communal regulation and privatization of sasi. Jurnal Ekonesia 2:1-38.

36. Xiuping \& Kissya, E, Yanes (2010) Indigenous Knowledge and Customary Law in Natural Resource Management: Experiences in Yunnan, China and Haruku, Indonesia. Thailand: Asia Indigenous Peoples Pact (AIPP) Foundation

37. Matitaputty, J. K Ali, M, Sjamsuddin, H, Maryani, E (2018) Contributions of Sasi to Sustainable Living of Saparua Indigenous Community, Indonesia. Advances in Social Science, Education and Humanities Research, volume 251. Published by Atlantis Press. Hal 685-691.

38. Liu, L (2009) Sustainability: Living within One's Own Ecological Means. Journal sustainability. Vol 1, doi:10.3390/su1041412. ISSN 2071-1050. PP, 1412-1430;

39. Matitaputty, J.K; Ali, M, Sjamsuddin, H, Maryani, E (2018) Model of Sustainable Development of Sasi from Maluku, Indonesia. Jour of Adv Research in Dynamical \& Control Systems, Vol. 10, 04-Special Issue hal. 981-984. 